\title{
Late-glacial Coleoptera and the paleoclimate at Hirtles, Nova Scotia
}

\author{
Randall F. Miller \\ Steinhammer Palaeontology Laboratory, New Brunswick Museum, \\ 277 Douglas Avenue, Saint John, New Brunswick E2K 1E5, Canada
}

Date Received May 1, 1995

Date Accepted July 20, 1995

\begin{abstract}
Paleoentomological studies of Coleoptera from a late-glacial site at Hirtles, Nova Scotia, Canada, produced a tundra-treeline to northern boreal assemblage during the interval 12,300 to 11,700 years B.P. This is one of the oldest late-glacial buried organic deposits in the Maritime Provinces of Canada and provides fossil beetle evidence for recently deglaciated environments in the region. Bark beetles indicate the presence of trees, perhaps as early as 11,900 years B.P. A comparison can be made with contemporaneous sites in central and eastern North America where coleopteran evidence suggests warmer temperatures. Coleoptera fossils demonstrate evidence of a climatic gradient from the Great Lakes to eastern Canada during this time interval possibly greater than occurs today.
\end{abstract}

Des études paléoentomologiques de coléoptères d'un emplacement tardiglaciaire, à Hirtes, en Nouvelle-Écosse, au Canada, ont permis l'établissement d'une limite de végétation des arbres et de toundra pour la florizone boréale septentrionale pendant l'intervalle de 12300 à 11700 ans avant le présent. Il s'agit de l'un des plus anciens dépôts organiques tardiglaciaires enfouis dans les provinces maritimes canadiennes; il fournit une preuve de l'existence de coléoptères fossiles dans la région. L'existence de scolytes révèle la présence d'arbres, peut-être dès 11900 ans avant le présent. On peut effectuer une comparaison avec des emplacements contemporains dans le centre et l'est de l'Amérique du Nord, où la preuve de la présence de coléoptères permet de supposer des températures plus chaudes. Les fossiles de coléoptères démontrent qu'il a existé pendant cet intervalle un gradient climatique possiblement supérieur à celui d'aujourd'hui, des Grands Lacs à l'Est du Canada.

[Traduit par la rédaction]

\section{INTRODUCTION}

Over the past decade a number of papers have discussed the late-glacial environment of Atlantic Canada, especially in relation to the Younger Dryas event. Mott et al. (1986a), Stea and Mott (1989), Mott and Stea (1993) and Mott (1994) summarized information gathered from a number of buried organic sites in Nova Scotia and provided stratigraphic interpretation, radiocarbon chronology and pollen records that have been used to piece together a picture of late-glacial environments from about 14,000 to 10,000 years B.P. Two field guides provide additional detail (Stea and Mott, 1990; Stea et al., 1992a) and much of the information has been compiled in map format (Stea et al., 1992b). The work has resulted in a detailed analysis of deglaciated environments and evidence for active glaciers of Younger Dryas age in Nova Scotia.

Many of the buried organic sites, especially those detailed by Stea and Mott (1989) and Mott and Stea (1993), are suitable for paleoentomological analysis and have been shown to contain beetle assemblages (Mott $e$ t al., 1986b; Miller, 1989; Stea and Mott, 1990; Miller and Morgan, 1991). This paper discusses the Coleoptera fauna from Hirtles on the coast of southern Nova Scotia (Fig. 1), a late-glacial site dated from 12,300 to 11,700 years B.P.

\section{SiTE DESCRIPTION}

The Hirtles site is located on the south shore of Nova Scotia west of Halifax, at $44^{\circ} 16^{\prime} 00^{\prime \prime} \mathrm{N} ; 6^{\circ} 15^{\prime} 50^{\prime \prime} \mathrm{W}$. The section consists of $15 \mathrm{~cm}$ of peat overlying $10 \mathrm{~cm}$ of silty peat which in turn overlies $15 \mathrm{~cm}$ of organic bearing silt (Fig. 1). Three radiocarbon dates are available for this site (Mott and Stea, 1993). A twig from the basal clay yielded an AMS date of 12,270 \pm 90 years B.P. (TO-3628). Two bulk samples date the organic unit at $12,300 \pm 150$ years B.P. (GSC-5247) at the base and 11,700 \pm 110 years B.P. (GSC-5248) at the top.

\section{Methods}

Samples of peat and organic-rich sediment totalling 190 $\mathrm{kg}$ were taken in thicknesses of $5 \mathrm{~cm}$ (Fig. 1) following standard techniques for the study of Quaternary beetle fossils (Elias, 1994). Sample size varied depending on sediment and accessibility. All samples were submitted to standard paleoentomological analysis using a kerosene floatation technique to isolate chitinous fragments (Elias, 1994). Untreated samples and processed residues were retained for other possible analyses. Identified Coleoptera specimens were mounted on micropaleontology slides or stored in alcohol and were cata- 


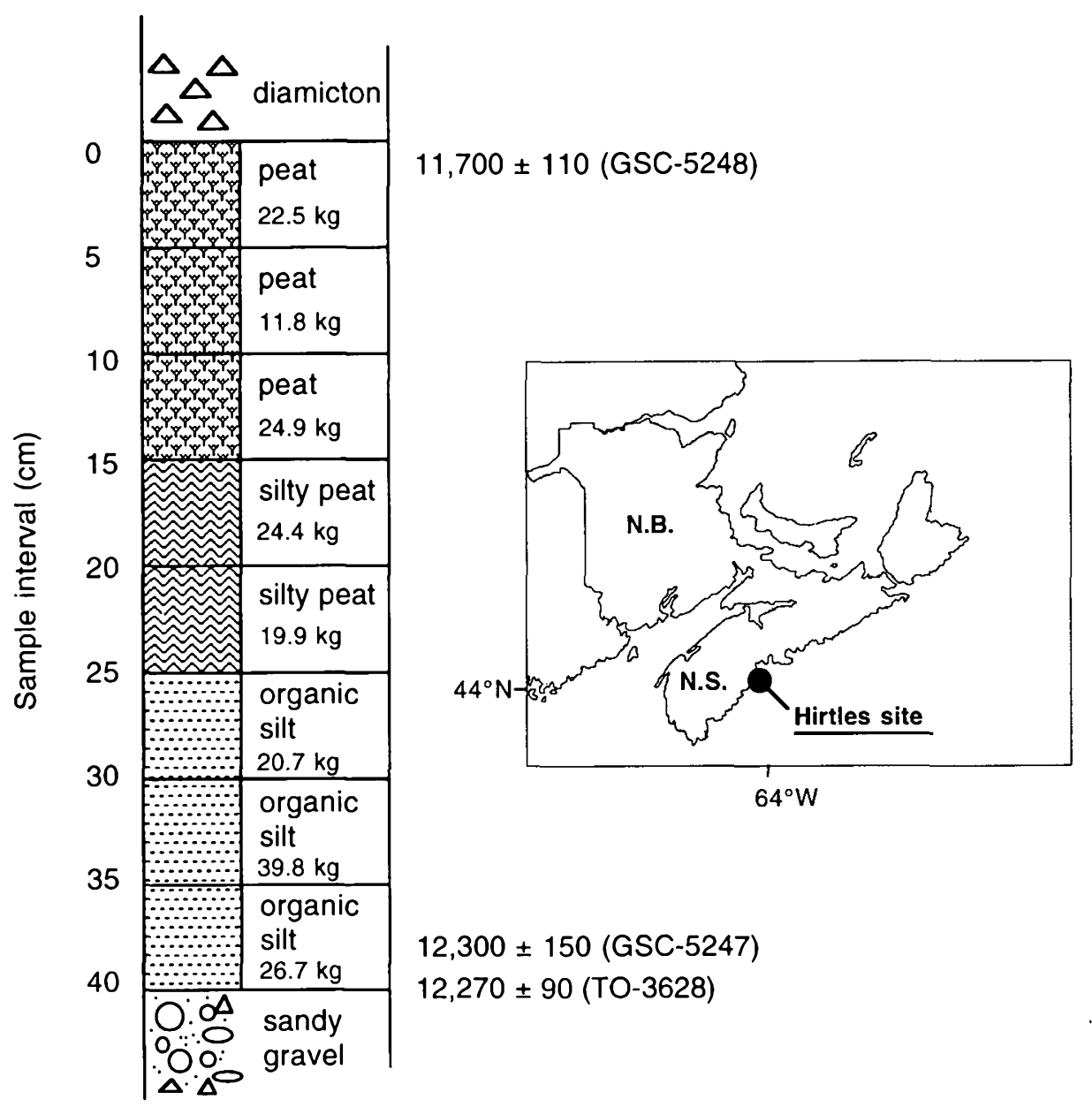

Fig. 1. Location, stratigraphy and radiocarbon chronology of late-glacial Hirtles site, Nova Scotia, Canada.

logued and counted. All specimens and samples, including residues are stored in the paleontology collections of the New Brunswick Museum.

\section{Paleoentomology}

A relatively abundant and well-preserved assemblage of beetles was found at the site (Table 1). A diverse fauna consisting largely of rove beetles (Staphylinidae) and ground beetles (Carabidae) was recovered with lesser numbers of others, including aquatic beetles (Dytiscidae and Hydrophilidae), pill beetles (Byrrhidae), click beetles (Elateridae), scarabs (Scarabaeidae) and weevils (Curculionidae). The assemblage included the ground beetles Bembidion scopulinum, Blethisa julii, Diacheila anctica, Patrobus septentrionis/foveocollis and Patrobus stygicus. Some of these species are found on coastal tundra in eastern Canada or have a northern boreal distribution. The staphylinid assemblage consists largely of Stenus, the omaliines, Olophrum rotundicolle, Geodromicus cf. G. verticalis and Eucnecosum tenue/brunnescens and two tachyporines, Nitidotachinus tachyporoides and Tachinus cf. T. jacuticus ullrichi. Most of the species are found today inhabiting the margins of wet areas, often standing or slowly moving water with sparse vegetation. A few species are found on the tundra but most are boreal species which may inhabit open ground. One interesting aspect of the Hirtles fauna is the presence of scolytids, beetles which inhabit trees.

\section{Description and modern distribution of selected species}

\section{Bembidion scopulinum}

This is a riparian ground beetle found at the margin of running and standing waters of any size and on all kinds of soil, barren or with quite sparse vegetation. It extends to the timber limit in the east but is not found on the tundra. It has a transamerican distribution but is more common in the east (Lindroth, 1963).

\section{Blethisa julii}

This ground beetle lives beside small bodies of water where there is some vegetation and some bare mud. It is a boreal species, not found above treeline (Fig. 2). The modern range of the species is from Newfoundland to Alberta and south into the mountains of New England (Lindroth, 1961; Morgan et al., 1986). 
Table 1. Coleoptera from the late-glacial Hirtles Site, Nova Scotia, Canada.

Sample intervals*

TAXA

$\begin{array}{llllllll}1 & 2 & 3 & 4 & 5 & 6 & 7 & 8\end{array}$

CARABIDAE * *

Agonum nr. affine

$\begin{array}{llllllll}0 & 11 & 4 & 9 & 7 & 37 & 11 & 25\end{array}$

Bembidion cf. B. grapei

Bembidion scopulinum

Bembidion spp.

Blethisa julii

cf. Carabus sp.

Cymindis sp.

Diacheila arctica

Elaphrus americanus gp.

Notiophilus sp.

Patrobus septentrionis/foveocollis

Patrobus stygicus

Patrobus spp.

Trechus cf. T. crassiscapus

gen. indet.

DYTISCIDAE

Ilybius $\mathrm{cf}$. I. angustior

gen. indet.

HYDRAENIDAE

Ochthebius cf. O. kaszabi

STAPHYLINIDAE

Acidota quadrata

Acidota cf. A. quadrata

Bledius sp.

Eucnecosum tenue/brunnescens

Geodromicus cf. G. verticalis

Geodromicus sp.

Gymnusa sp.

cf. Ischnosoma/Mycetoporus

Lathrobium

cf. Mycetoporus

Nitidotachinus tachyporoides

Olophrum rotundicolle

Philonthus spp.

Stenus spp.

cf. Stenus

Tachinus cf. T. jacuticus ullrichi

Tachinus sp.

Aleocharinae

Omaliinae

HYDROPHILIDAE

Helophorus cf. H. sempervarians

SCARABAEIDAE

Aegialia cf. A. lacustris

Aphodius sp.

$\begin{array}{lllll}1 & & & & \\ 3 & 2 & & & \\ 5 & & 1 & 1 & \\ & & & 1 & 1 \\ 1 & & 1 & & \end{array}$

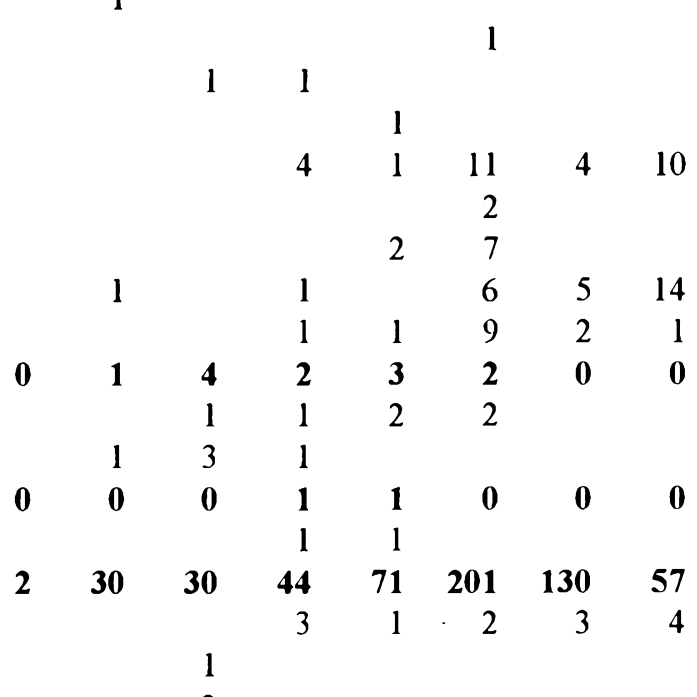

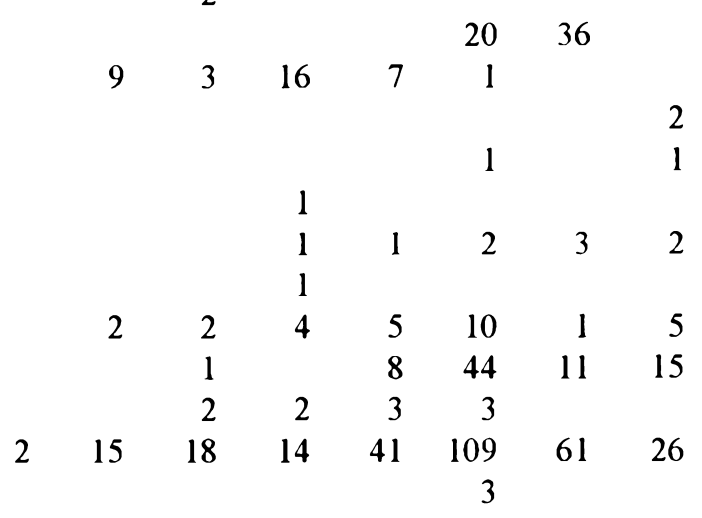

$\begin{array}{rrrrrrrr} & 1 & & & & & & \\ & 3 & & & & & \\ & & 1 & 2 & 5 & 6 & 11 & 2 \\ \mathbf{0} & \mathbf{0} & \mathbf{0} & \mathbf{1} & \mathbf{0} & \mathbf{0} & \mathbf{0} & \mathbf{0} \\ \mathbf{0} & \mathbf{3} & \mathbf{1 1} & \mathbf{1 0} & \mathbf{3} & \mathbf{8} & \mathbf{3} & \mathbf{3} \\ & 2 & 10 & \mathbf{8} & 2 & 5 & 1 & 2 \\ & 1 & 1 & 2 & 1 & 3 & 2 & 1\end{array}$

$* \mathrm{~cm}$ levels $1=35-40 ; 2=30-35 ; 3=25-30 ; 4=20-25 ; 5=15-20 ; 6=10-15 ; 7=5-10 ; 8=0-5$

** total number of individuals for each Family 
Table 1. Coleoptera from the late-glacial Hirtles Site, Nova Scotia, Canada, Continued.

Sample intervals*

TAXA

$\begin{array}{llllllll}1 & 2 & 3 & 4 & 5 & 6 & 7 & 8\end{array}$

BYRRHIDAE

Cytilus alternatus

cf. Curimopsis

Simplocaria sp.

gen. indet.

ELATERIDAE

Hypnoidus spp.

gen. indet.

COCCINELLIDAE

cf Scymnus/Nephus

CHRYSOMELIDAE

gen. indet.

CURCULIONIDAE

cf. Notaris

gen. indet. A

gen. indet. $\mathrm{B}$

SCOLYTIDAE

gen. indet. $\begin{array}{llllllll}\mathbf{0} & 1 & \mathbf{1} & \mathbf{1} & \mathbf{1} & \mathbf{2} & \mathbf{1} & \mathbf{0} \\ & 1 & & & & 1 & 1 & \end{array}$

1

$\begin{array}{llllllll} & & 1 & & & 1 & & \\ & 4 & 2 & 0 & 1 & 1 & 0 & 0\end{array}$

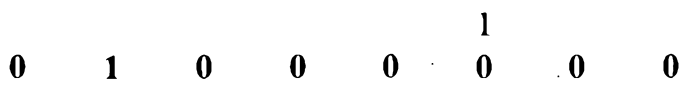

$\begin{array}{llllllll} & 1 & & & & & & \\ 0 & 0 & 0 & 0 & 1 & 0 & 1 & 0\end{array}$

$\begin{array}{llllllll}0 & 0 & 1 & 0 & 2 & 26 & 2 & 3\end{array}$

1

$\begin{array}{lllllll}\mathbf{0} & \mathbf{0} & \mathbf{0} & \mathbf{0} & \mathbf{0} & \mathbf{2} & \mathbf{1} \\ & & & & & 2 & 1\end{array}$

$* \mathrm{~cm}$ levels $1=35-40 ; 2=30-35 ; 3=25-30 ; 4=20-25 ; 5=15-20 ; 6=10-15 ; 7=5-10 ; 8=0-5$

** total number of individuals for each Family

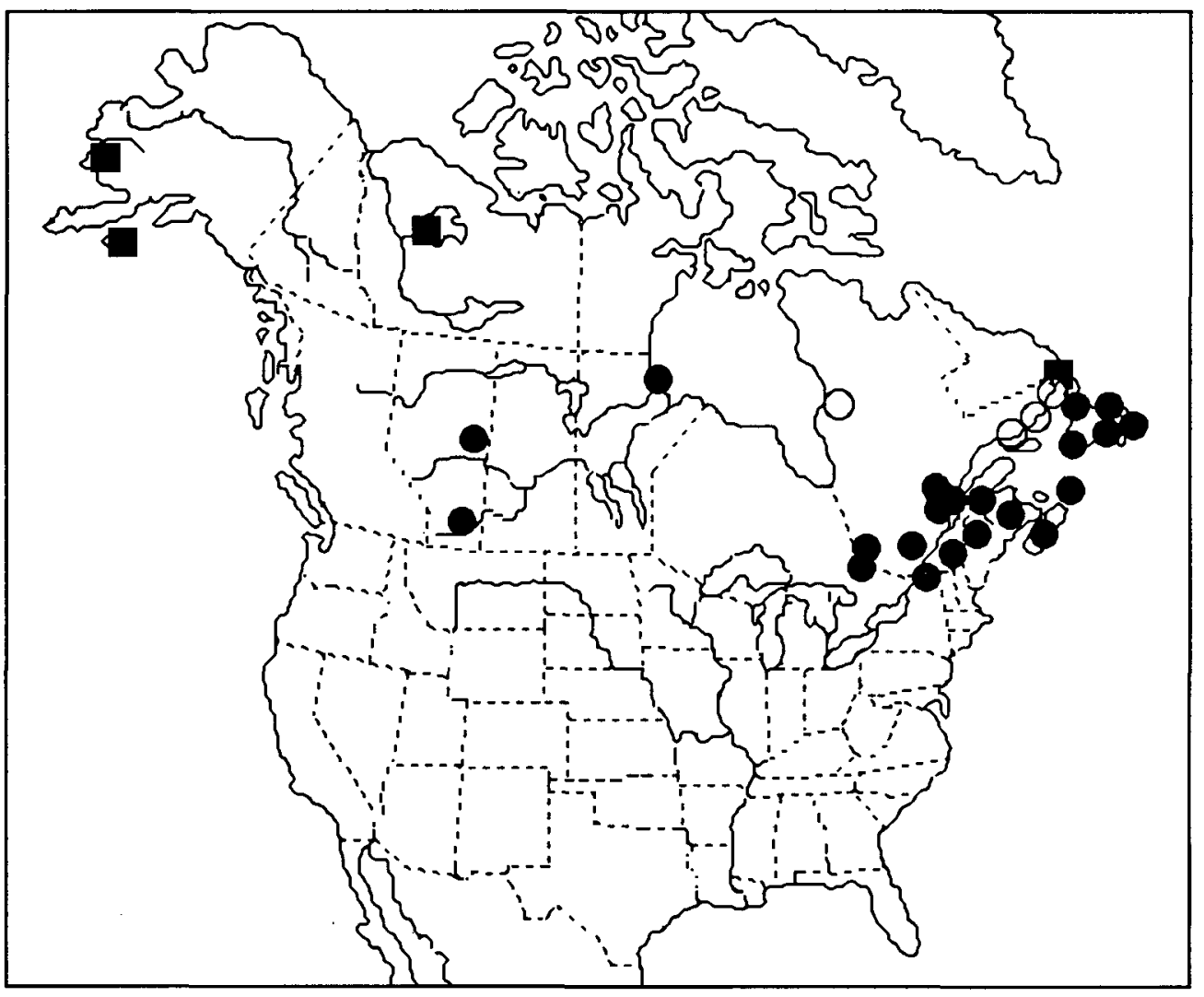


arctica, (O) Tachinus jacuticus ullichi. 


\section{Diacheila arctica}

A strongly hygrophilous ground beetle whose habitat includes boggy heath some distance from spruce forest. It is found in the extreme north and is very rare (Fig. 2). In Canada it has been collected in the Northwest Territories, Labrador as well as Alaska (Lindroth, 1961).

\section{Patrobus septentrionis/foveocollis}

These ground beetles are found at the edge of lakes, ponds and streams with moss. They are transamerican, boreal species, and sometimes are found on tundra. P. septentrionis is found beyond the forest only in southern Labrador on the coastal tundra and in Alaska, not on true tundra. Some prefer open ground along water margins (Lindroth, 1961).

\section{Nitidotachinus tachyporoides}

It is found in cool, wet habitats such as Sphagnum moss. It has been collected from floating river debris and by sifting deciduous leaf litter from a lake margin. This is a transcontinental species. It occurs from Newfoundland south to Massachusetts and Ohio and west to Terrace, British Columbia. It extends south along the Coast Range to central California and south in the rockies to Colorado (Campbell, 1973, 1988).

\section{Tachinus jacuticus ullrichi}

This species has been collected from clumps of grass in wet areas and by sifting fungi and bark from Populus. It is a transcontinental species ranging from Labrador to Alaska (Campbell, 1973, 1988), although the subspecies $T$. jacuticus ullrichi is known only from eastern North America (Fig. 2).

\section{SUMMARY OF THE PALEOENVIRONMENT}

At 13,000 years B.P. all or most of Nova Scotia was covered by ice (Stea and Mott, 1989; Stea et al., 1992b). By 12,000 years B.P. glaciers had retreated toward the highlands of central mainland Nova Scotia and Cape Breton Island leaving some coastal areas ice-free (Fig. 3). Organic accumulation at Hirtles began sometime around 12,300 years B.P. making this one of the oldest recorded buried organic sites in Nova Scotia (Mott and Stea, 1993). The beetle assemblage suggests a northern boreal to treeline environment. Those species in the assemblage which today live on tundra are not necessarily restricted to tundra, but are also inhabitants of open ground, riparian situations. Some of the species found at Hirtles have been found together in the modern environment of the Ungava region of Quebec (Morgan, 1989) where mean July temperatures are about 9 to $10^{\circ} \mathrm{C}$, but also farther south on the Labrador coast near Red Bay where mean July temperatures are about $12^{\circ} \mathrm{C}$ (Fig. 2). The open coastal treeline-shrub tundra of the southern Labrador coast might provide a good modern analogue for the conditions at Hirtles 12,000 years ago.

Between 12,000 and 11,000 years B.P. (Fig. 4) glaciers in Nova Scotia retreated to smaller local ice caps in the highland regions (Stea and Mott, 1989; Stea et al., 1992b). The composition of the beetle assemblage at Hirtles remained relatively stable over the 600 years recorded; however, by about 11,900 years B.P. (by extrapolation between radiocarbon dates) the to-

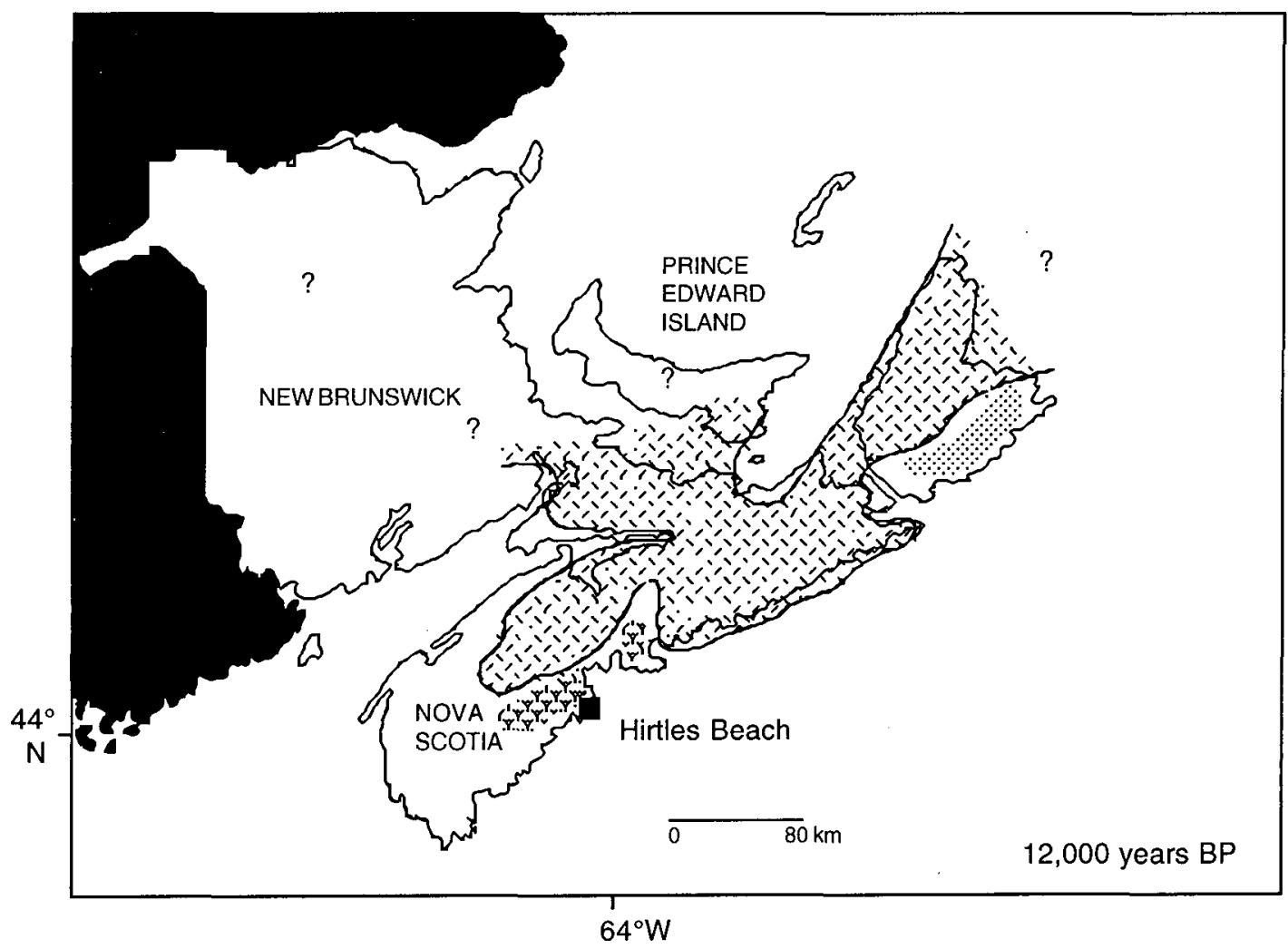

Fig. 3. Approximate ice position and nature of vegetation in relation to late-glacial buried organic site at Hirtles, Nova Scotia, Canada at about 12,000 years B.P. 

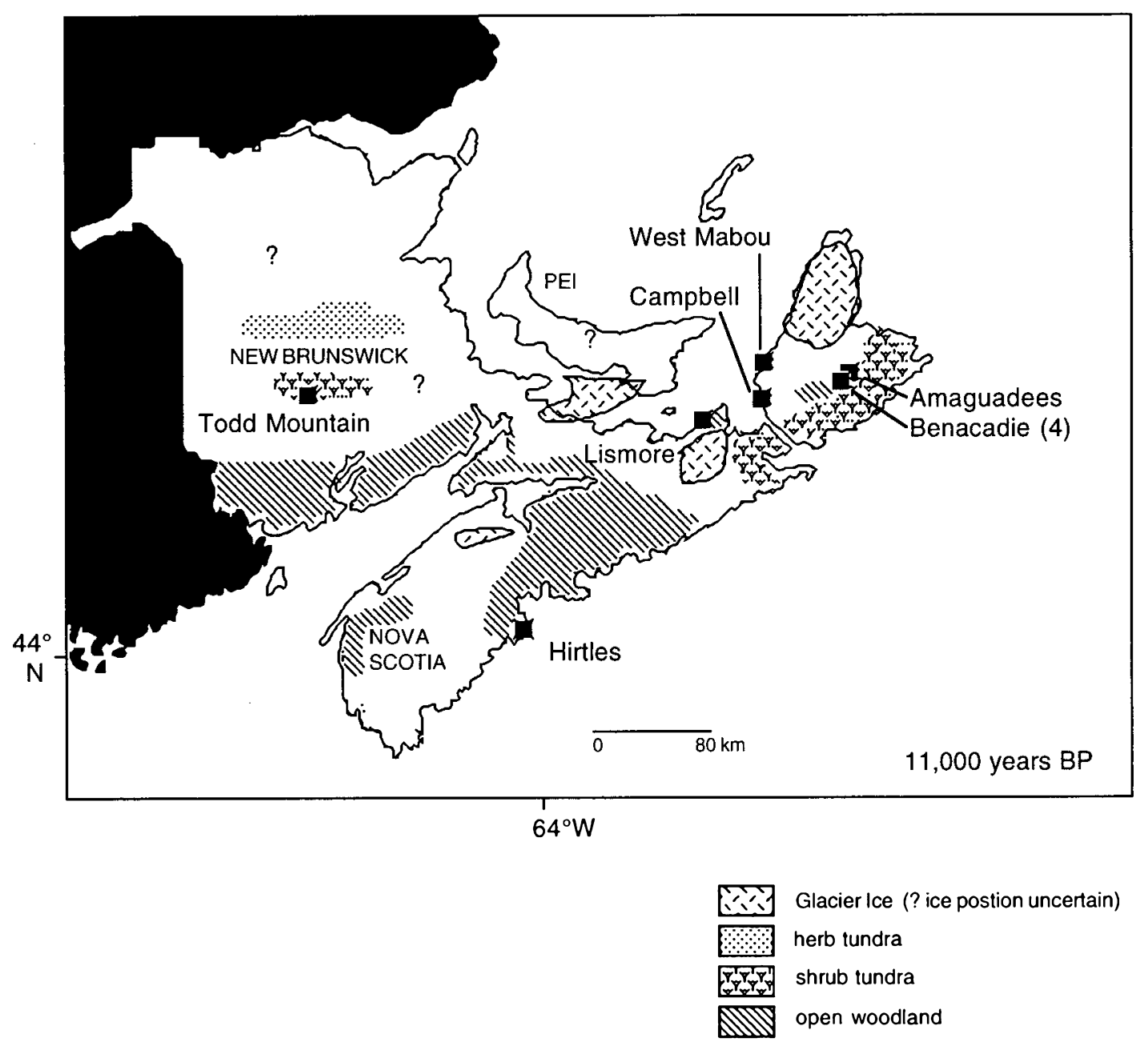

Fig. 4. Approximate ice position and nature of vegetation in relation to late-glacial buried organic site at Hirtles and other late-glacial sites in Nova Scotia and New Brunswick, Canada between 12,000 and 11,000 years B.P. (Mott et al., 1986a; Miller, 1994).

tal numbers of species and diversity increased and began to include more species typical of the boreal forest. Diacheila arctica, a rare northern ground beetle, occurred in samples of this age. The only modern occurrence of this species in the east is Red Bay, Labrador (Fig. 2). At the same time scolytid or bark beetles appeared, a good indication of trees growing nearby and in general agreement with the distribution of open woodland/ boreal forest suggested by pollen analysis (Stea and Mott, 1989; Mott, 1994). By about this time scolytids also were present at Lismore, Nova Scotia (Fig. 4) (Miller and Morgan, 1991). Bark beetles are often found under the bark of conifers where they build galleries and feed on wood.

\section{Discussion}

The Coleoptera recovered from late-glacial sites in Nova Scotia and New Brunswick (Fig. 4) illustrate three recognizable phases based upon the presence of one or more species (Miller, 1994). The periods can be divided into (1) a tundra/ tree-line assemblage older than about 11,800 years B.P., (2) a boreal assemblage from 11,800 to 10,800 years B.P., and (3) a northern boreo-montane assemblage from 10,800 to about 10,400 years B.P. Mean July temperatures for these assemblages, based on modern species distribution, are probably in the range of (1) $<9$ to $12^{\circ} \mathrm{C}$, (2) 14 to $18^{\circ} \mathrm{C}$, and (3) 12 to $15^{\circ} \mathrm{C}$ respectively. The Coleoptera assemblages described here fall into periods 1 and 2 and represent the transition from the tundra-treeline to boreal phase, although the site appears to represent a largely boreal situation.

The sequence of Coleoptera events recorded at Hirtles is out of step with events in central North America (Morgan et al., 1984) where beetle evidence suggests warmer temperatures before 12,000 years B.P. The most complete published coleopteran sequence is from Gage Street in southwestern Ontario (Schwert et al., 1985) where, at 12,800 years B.P., the assemblage contained open ground and boreal species, including bark beetles. The mean July temperatures were estimated at 15 to $17^{\circ} \mathrm{C}$. At the Winter Gulf site in western New York (Schwert and Morgan, 1980) 12,700 to 12,500 years B.P., the beetle fauna suggested an open mire surrounded by trees and mean July temperatures of greater that $16^{\circ} \mathrm{C}$. At the same time at Nichols Brook, New York, the coleopteran fauna suggests conditions similar to the middle of the present boreal zone (Fritz et al., 1987). Compared with the southwestern Ontario region where open ground to boreal conditions, including the presence of bark beetles, seem to have been established by 13,000 to 12,500 years 
B.P., colder conditions persisted at Hirtles to younger than 12,000 years ago. By 12,300 years B.P. mean July temperatures in southwestern Ontario were 15 to $17^{\circ} \mathrm{C}$ while at Hirtles in southern Nova Scotia temperatures of 10 to $12^{\circ} \mathrm{C}$ are indicated, a difference of about $5^{\circ} \mathrm{C}$. Today the mean July temperature recorded in southwestern Ontario at London is $20.5^{\circ} \mathrm{C}$ and at Halifax, Nova Scotia $17.6^{\circ} \mathrm{C}$ (Hare and Thomas, 1974), a difference of $3^{\circ} \mathrm{C}$. This suggests a climatic gradient during the early part of the late-glacial that may have been steeper than seen today.

\section{ACKNOWLeDGements}

Thanks to R. Stea (NSDME) and R. Mott (GSC) for identifying the field site discovered by R. Taylor (GSC) and for access to information, T. Fletcher for fieldwork, C. Clayton for technical assistance, A.V. Morgan for access to UW Quaternary Entomology Laboratory collections, and the CNC-Coleoptera staff of Agriculture Canada. This work was supported by National Geographic Society Research Grant 4588-91.

Campbell, J.M. 1973. A revision of the genus Tachinus (Coleoptera: Staphylinidae) of North and Central America. Entomological Society of Canada, Memoir 90, 137 p.

- 1988. New species and records of North American Tachinus Gravenhorst (Coleoptera: Staphylinidae). The Canadian Entomologist, 120, pp. 231-295.

EliAS, S.A. 1994. Quaternary Insects and Their Environments. Smithsonian Institution Press, Washington, $284 \mathrm{p}$.

Fritz, P., Morgan, A.V., Eicher, U., and McAndrews, J.H. 1987. Stable isotope, fossil Coleoptera and pollen stratigraphy in late Quaternary sediments from Ontario and New York State. Palaeogeography, Palaeoclimatology, Palaeoecology, 58, pp. 183-202.

Hare, F.K. and Thomas, M.K. 1974. Climate Canada. Wiley, Toronto, $256 \mathrm{p}$.

Lindroth, C.H. 1961. The ground beetles of Canada and Alaska, 2. Opuscula Entomologica, Supplementum 20, pp. 1-200.

- 1963. The ground beetles of Canada and Alaska, 3. Opuscula Entomologica Supplementum, 24, pp. 201-408.

MilleR, R.F. 1989. Fossil Coleoptera studies of Late-glacial sites in Nova Scotia. Atlantic Geology, 25, p. 165.

1994. Paleoentomological analysis of the Late-glacial/Younger Dryas in eastern Canada. Program with Abstracts, Geological Association of Canada, Mineralogical Association of Canada, Joint
Annual Meeting, Waterloo 1994, 19, p. A76.

Miller, R.F. and MORGAN, A.V. 1991. Late-glacial Coleoptera fauna from Lismore, Nova Scotia. Atlantic Geology, 27, pp. 193-197.

Morgan, A.V. 1989. Coleoptera along Eastem Ungava Bay, Québec: Part 1, Carabidae. Naturaliste Canadien, 116, pp. 27-34.

Morgan, A.V., Morgan, A., Ashworth, A.C., and Matthews, J.V., JR. 1984. Late Wisconsin Fossil Beetles in North America. In Late Quaternary Environments of the United States, Volume 1, The Late Pleistocene. Edited by S.C. Porter. Longman, London, pp. 354-363.

Morgan, A.V., Morgan, A., Nelson, R.E., and Pilny, J.J. 1986. Current Status of Knowledge on the Past and Present Distribution of the Genus Blethisa (Coleoptera : Carabidae) in North America. Coleopterists' Bulletin, 40, pp. 105-115.

Mort, R.J. 1994. Wisconsinan Late-glacial environmental change in Nova Scotia: a regional synthesis. Joumal of Quatemary Science, 9, pp. 155-160.

Mott, R.J. and StEA, R.R. 1993. Late-glacial (Allerod Younger Dryas) buried organic deposits, Nova Scotia, Canada. Quaternary Science Reviews, 12, pp. 645-657.

Motr, R.J., Grant, D.R., Stea, R.R., and Occhietti, S. 1986a. Late-glacial climatic oscillation in Atlantic Canada equivalent to the Allered-Younger Dryas event. Nature, 323, pp. 247-250.

Mott, R.J., Matthews, J.V., JR., Grant, D.R., and Beke, G.J. 1986b. A late glacial buried organic profile near Brookside, Nova Scotia. Current Research, Part B, Geological Survey of Canada, Paper 86-1B, pp. 289-294.

Schwert, D.P. and Morgan, A.V. 1980. Paleoenvironmental implications of a Late Glacial insect assemblage from northwestern New York. Quaternary Research, 13, pp. 93-110.

Schwert, D.P., Anderson, T.W., Morgan, A., Morgan, A.V., and KARROW, P.F. 1985. Changes in Late Quatemary vegetation and insect communities in southwestem Ontario. Quaternary Research, 23, pp. 205-226.

STEA, R.R. and Motr, R.J. 1989. Deglaciation environments and evidence for glaciers of Younger Dryas age in Nova Scotia, Canada. Boreas, 18, pp. 169-187.

- 1990. Quaternary Geology of Nova Scotia; Guidebook for 53rd Annual Friends of the Pleistocene Field Excursion. Nova Scotia Deptartment of Mines and Energy, Open File Report 90-008, 85 p.

SteA, R.R., Forbes, D.L., and MotT, R.J. 1992a. Quaternary Geology and Coastal Evolution of Nova Scotia. Geological Association of Canada, Mineralogical Association of Canada, Joint Annual Meeting, Wolfville 1992; Field Excursion A-6, Guidebook, 125 p.

Stea, R.R., Conley, H., and Brown, Y. 1992b. Surficial Geology of the province of Nova Scotia. Nova Scotia Department of Natural Resources, Map 92-3, Scale 1:500,000. 